\title{
屋内環境中の窒素酸化物に関する研究（その 2 )
}

質問紙調査と計算による二酸化窒素年平均室内濃度の推定

$\begin{array}{llll}\text { 正会員山 } & \text { 中 } & \text { 伸 } & \text {-* } \\ \text { 正会員山 } & \text { 本 } & \text { 行 } & \text { 隆** }\end{array}$

\section{1.はじめに}

前報1)では初めに家庭用知焼器具のいくつかについ て, 二酸化窒素 (以下 $\mathrm{NO}_{2}$ ) の発生速度を求め, 提示 した。続いて，構造材料を異にする二種の部屋における $\mathrm{NO}_{2}$ の挙動を比較しながら，その室内濃度変動に影響 を与える要因について検討し，換気回数以外に相対湿度 と室内材（材質と表面積）が重要であることを示した。

以上の結果を利用すると，次のような二種類の $\mathrm{NO}_{2}$ 室内濃度にアプローチすることができる。一つは部屋の 種類や広さと暖房器具の種類を仮定し，相対湿度と換気 回数をパラメータに, $\mathrm{NO}_{2}$ の短時間での濃度変動を解 析し，予測する方法であり，もう一つは現実の家庭にお ける居間と暖房に関する生活情報から，平均的な，長時 間にならした $\mathrm{NO}_{2}$ 室内濃度（例えば年平均値）を推定 する方法である。ここでは後者について検討することと した。

すでに報告したように2)，室内で然焼器具を使用する 場合の $\mathrm{NO}_{2}$ のピーク濃度は次式で与えられる。

$$
C_{\rho}=E /((a+k) V\}+a C_{0} /(a+k) \cdots
$$

ここで, $C_{p}: \mathrm{NO}_{2}$ の室内最高濃度 $(\mathrm{ppm}), E$ : 使用 中の然焼器具の $\mathrm{NO}_{2}$ 発生速度 $\left(\mathrm{cm}^{3} / \mathrm{h}\right), a$ : 換気回数 $(1 / \mathrm{h}), k$ : 反応係数 ${ }^{1)}(1 / \mathrm{h}), V$ : 室容積 $\left(\mathrm{m}^{3}\right), C_{0}$ ： $\mathrm{NO}_{2}$ 屋外濃度 $(\mathrm{ppm})$ である。さてこの式を用いて $\mathrm{NO}_{2}$ の平均的な室内濃度を推定しようとするとき, 解 決しなければならない点は, 最高濃度と平均濃度の関連 づけをどのようにするのかということと，換気回数 $a$ と反応係数 $k$ をどのように与えるのかということであ る。

ここでは初めに予備調査として実測値と計算値の照合 を行って，計算式に補正係数を導入し，次に本調査とし て質問紙調查を実施して必要な情報を入手し，上記計算 方法を応用した結果について報告する。

\section{2. 方 法}

2-1 計算式検証のための予備調查（補正係数の決定） 冬期に，延べ三十の家庭に協力を依頼し，各居間に市

* 京都市衛生研究所

** 京都市立看護短期大学 (昭和 61 年 8 月 8 日原稿受理)
販の柳沢式フィルターバッデ3)を一定期間設置してもら い, 当該室内の $\mathrm{NO}_{2}$ 積算濃度（ppb・day）を測定した。 同時に, “喛房に関する事項（器具の種類，测定期間中 の正確な使用時間)”之“部屋に関する事項（種類「和 室か洋室加，広さ，台所との位置的関係)”について調 查した。そして “暖房に関する事項”と「部屋の広さ」


間数）を算出し，フィルターバッヂによる実測値との比 を求め，その各々について “部屋に関する事項”との関 係を詳細に解析した。なおこのとき，屋外からの $\mathrm{NO}_{2}$ の影響については, 昭和 58 年度の常時監視のデータの うち，当該住宅に最も近い観測局の冬期四ケ月の平均値 をフィルターバッヂの実測値から差引いて補正した。ま たフィルターバッヂは次項に述べる方法により，比色分 析値（吸光度）から積算濃度へ換算式を求めた。

以上の概念をさらに図で説明すると以下のようにな る。通常, 暖房器具の点火から消火およびそれに続く一 定の時間内の $\mathrm{NO}_{2}$ の濃度変化の態様はおよそ図—1(a)

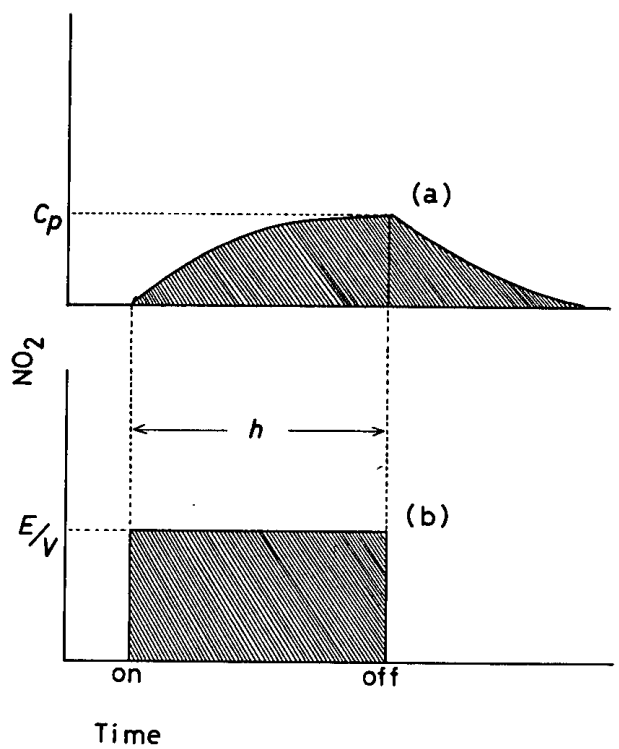

Fig. 1 Variation pattern of indoor $\mathrm{NO}_{2}$ level and the simulated model for calculation

注 1) 定数 24 は単位を（ppb·hour）から（ppb·day）に変 換するためのものである。なお，ppm から ppbへの係数 は省略した（以下同じ）。 
のようになるはずである。フィルターバッヂで捕集され る，したがって人が暴露される $\mathrm{NO}_{2}$ 量はこの曲線の下 側の面積に比例する。一方， $(E / \mathbb{V}) h$ は図一1(b) で示 す長方形の面積である。この長方形の面積を補正係数で 除して同図（a）の曲線下の面積の推定値とするのがこ こでの趣旨である。

2-1-1 フィルターバッヂ分析值（吸光度）から $\mathrm{NO}_{2}$ 積算濃度 (ppb·day) への換算

使用したフィルターバッヂは柳沢ら゙)によって考案さ れたもので, $\mathrm{NO}_{2}$ と固有の反応をする試液を含浸させ た潡紙によって空気中 $\mathrm{NO}_{2}$ を吸着・捕集し、これをそ のまま比色分析に供して $\mathrm{NO}_{2}$ の積算浱度を得ることが できる。操作は簡便であり，信頼性も高い。ただし，吸 光度から積算濃度を求めるための検量線が必要である。 ここでは予備調㚗に先立って, 地上約 $20 \mathrm{~m}$ の建物屋上 に時期を変えて都合 10 回，フィルターバッヂを 1 ～2 日 間暴露し，常法によって測定値（吸光度）を得た。同時 に隆接する大気污染観測局における当該暴露期間の平均 灙度に暴露時間を垂じて（ppb・day）を求めた。これら 二つの值の間の相関を図一 2 に示す。最小自乗法による 回帰式は次のとおりである。

$$
Y=117 X-4.2 \quad(n=10)
$$

ここで, $Y$ は $\mathrm{NO}_{2}$ 積算濃度 (ppb·day)，Xは吸光度 （発色液 $20 \mathrm{ml}$, 波長 $545 \mathrm{~nm}$, 光路長 $10 \mathrm{~mm}$ ）とする。 予備調直における実測值は上記の式を用いて求めた。

2-1-2 予備調㚗における部屋および暖房に関する調 㚗項目

予備調亘の対象家庭において行った標記の項目は次の とおりである。

(1) 住所地

（2）住宅：(木造・鉄筋コンクリート・その他)

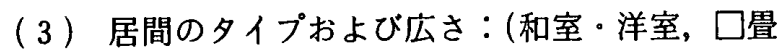
相当)

同上の台所との位置的関係：(LDK・鲜接・

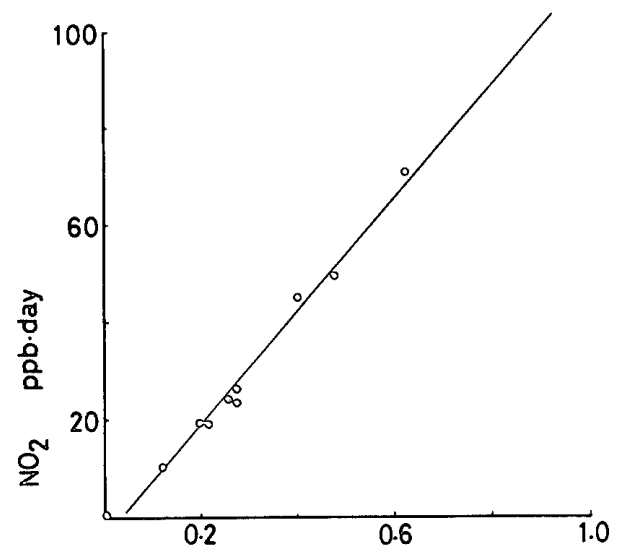

Absorbance

Fig. 2 Absorbance vs. $\mathrm{NO}_{2}$ integrated concentration relationship

\section{独立)}

（4）暖房方式: 石油ストーブ (反射型・対流型), ガスストーブ (赤外線・スケルトン), ファンヒー 夕(石油・ガス), 給排気式クリーンヒータ, エ アコン,その他

(5) 盀煙者: (有・無)

（6）フィルターバッヂ暴露時間

（7）その間の暖房器具運転の延べ時間

2-2 質問紙調㚗 (本調㸖)

標育抽出は全京都市域の住民基本台帳によって，町別 にその世带数の百分の一になるように行った。

これらの対象世帯に質問紙を郵送し，記入回答を依頼 した。全配布数は 5000 (抽出率 $1 \%$ ) である。質問事 項は前項に示した調亘項目を踏撉し（ただし6，7項は 除く)，それに「一日の平均の暖房時間」および「年間 の暖房期間 (月数)」を追加した。

\section{2-3 $\quad \mathrm{NO}_{2}$ 室内濃度の試算}

\section{2-3-1 使用した定数}

(1) 式における $\mathrm{NO}_{2}$ の発生速度 $E$ は; 器具別に前 報”で示した值を $25^{\circ} \mathrm{C} ， 1$ 気圧の值に換算して用いた。

次に室容積 Vについて，質問では疊の数で問うてい る。したがって室容積を算出するには畳一枚の広さと天 井高が必要となる。現在普及している畳は，広い方から 京間, 田舎間, 江戸間, 団地サイズ等幾種頪かある。こ れらがよ゙のように分布しているのかまでは調べられてい ない。同様に天井高についてもさまざまの值があり得よ う。ここではあくまで平均的な数值を求める立場から， 盢は江戸間サイズ $\left(1.76 \times 0.88 \mathrm{~m}^{2}\right)$, 天井高は $2.4 \mathrm{~m}$ と した。

\section{2-3-2 年間積算濃度から年平均濃度への換算}

暖房は季節と密接なかかわりがあり，主として冬期に 利用されることは論を待つまでもない。そして季節は一 年を周期として巡りくることも自然の原理である。そこ で，ある住宅室内の $\mathrm{NO}_{2}$ 湄度の平均値は, 年間の積算 潄度（ppb·day）（その大部分が冬期に起源を持つ）を 算出し，その值を一年の日数 365 で除すれば得られるは



Fig. 3 Variation patterns of indoor $\mathrm{NO}_{2}$ level through a year and the simulated model for calculation 
ずである。この概念を図で説明すると以下のとおりであ る。今, 縦軸に $\mathrm{NO}_{2}$ 濃度 $(\mathrm{ppb})$, 横軸に時間 $(h)$ をと ると，冬期の暖房期間中の $\mathrm{NO}_{2}$ 室内濃度はおよそ図一 3 (a)に示したようなパターンの繰り返しになるであろう。 このピークは一日に一個の場合もあれば二個以上の場合 もあるであろう。すでに述べたように $\mathrm{NO}_{2}$ の積算濃度 はこれらの曲線下の面積の合計であり，年間の述べ暖房 時間を $h$ とすると，その推定値は $(E / V)(1 / F)(h / 24)$ となる(ここで $F$ は 2-1 項で決定した補正係数である)。 そしてさらにこれを 365 (日) で除したものが求める年 平均値 $C_{m}(\mathrm{ppb})$ となる。すなわち

$$
C_{m}=(E / V)(1 / F)(h / 24)(1 / 365)
$$

これを図で示すと図一3(b) となる。同図（a) の曲 線下の面積の合計を一年間にならし, 同一面積の長方形 にしたのが同図（b) に外ならない。C $C_{m}$ はその高さに 相当している（ただしここではバックグラウンドは無視 している)。

以上の方法により, 年平均の $\mathrm{NO}_{2}$ 室内濃度を算出し た。

\section{3. 結果と考察}

\section{3-1 予備調查の結果による補正係数}

予備調査において得られた計算値 $(E / V)(h / 24)$ と フィルターバッデによる実測値との比 $\left(f_{t}\right)$ を, 全 30 デー 夕のうち明らかに異常な值であった 2 データを除く残り のデータについて解析した。その統計量を示すと以下の とおりである。 $n: 28$, 平均値 $: 3.15$, 標準偏差 $: 2.33$, 最大値: 7.8 , 最小值 $: 0.45$, 中央値 $: 2.39$ 。

これらデータの各々について，前揭 “部屋に関する調 查事項”との関係を解析した。すなわちまず, 住宅（居 間）を下記のように四種に分類し，各グループごとに $f_{i}$ の平均值 $\left(F_{i}, i=1 \sim 4\right)$ を求めた。次にその $F_{t}$ で 補正した值: $(E / V)(h / 24)\left(1 / F_{t}\right)$ の, 実測值 $(\mathrm{ppb} \cdot$ day) に対する比を全 28 データについて算出し，これらがで きるだけ 1 に近くなるように，前記平均值 $\left(F_{i}\right)$ の修正 を試みた。このことを試行錯誤的に繰り返して，下記の ように補正係数（ $F$ 値）を決定したものである。

（I） 台所と一体もしくは隣接の和室 $: 3.5$

（II） 同上の洋室 :2

（III） 台所からまったく離れている和室：7

(IN) 同上の洋室 $: 5$

このように $F$ 值は「洋室」より「和室」が,「台所と 一体もしくは隣接したもの」より「まったく離れている もの」が大きい值を示した。（1）式からも分かるよう に $F$ 值は诚衰係数： $(a+k)$ に相当する。その要因のう ち, 換気回数は一般に洋室より和室の方が大きいとされ ている。また反応による減衰要因について考えてみると， すでに報告したように和室には共通して畳と塗り壁が あって, 一定の $\mathrm{NO}_{2}$ 収着能が期待できるのに対し, 洋
室では床材，壁材等は多種多様なものが考えられる。し かし少なくとも壁材は“塗り壁”より表面積の小さい， 平滑な高分子材料が多い。床材についても，カーペット 使用の場合を除き，やはり “畳”より表面積の小さいも のが多く，その $\mathrm{NO}_{2}$ 収着能は和室より劣るであろう。 次に台所の影響についてであるが，今回は調理器具から の $\mathrm{NO}_{2}$ は計算にいれていない。一方フィルターバッヂ はこれも捕集・測定する。その結果，「台所と一体もし くは隣接」する部屋では $F$ 值が相対的に小さくなった ものと考えられる。

以上のように，今回得られた $F$ 值の示す傾向は，す でに報告した $\mathrm{NO}_{2}$ の減衰要因に関する知見や, 換気回 数, 反応係数のとり得る值の範囲とも矛盾がなく，妥当 な値であることが分かる。

次に念のため，上記のようにして得られた $F$ 值で補 正した計算值：(E/V)( $h / 24)(1 / F)$ とフィルターバッヂ の実測値との比に関する統計量を示すと，次のとおりで ある。 $n: 28$, 平均値 $: 1.01$, 標準偏差 $: 0.32$, 最大値 $: 1.56$, 最小值: 0.45 , 中央値 $: 1.07$ 。

計算値と実測值の関係を図一4に示す。図で分かるよ うに, 低濃度では実測値が高く, 高濃度では逆に計算値 が高くなる傾向が認められる。したがってこのF值を 使用した濃度予測は，高濃度域でやや過大評価になる恐 れがあるが, 安全側 (現実の濃度より予測値が高ければ, それだけ環境の評価を厳しくすることになる) の観点に 立って, 敢えてこの $F$ 值を採用し，以下の計算を行う こととした。

\section{3-2 質問紙回答集計結果}

質問紙は総配布数 5000 , 回収されたもの 4101 (回収 率： $82 \%$ ）であった。ただし有効回答数は，記載不備 等があって各項目により異なる。以下主要な三つの項目 について集計結果を概観する。

\section{3-2-1 暖房器具の種類}

暖房器具の器種別分布状況を円グラフにして図一 5 に



Fig. 4 Correlation between the calculated values of indoor $\mathrm{NO}_{2}$ level and the experimental values 


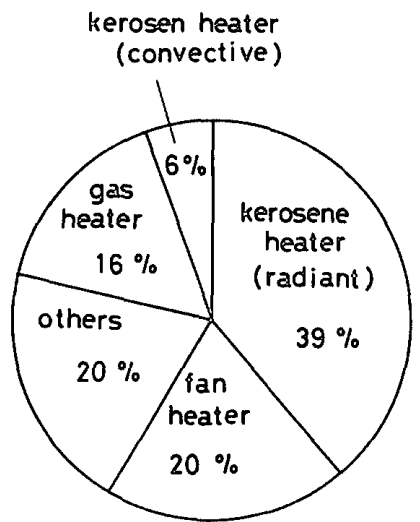

Fig.5 Relative percent frequencies of space heaters used

示す（有効回答效：3122）。最も多く利用されているの は反射型石油ストーブで，全体の $39 \%$ であった。続い てファンヒータ（石油およびガス）と「その他」が各 $20 \%$ であった。ここで「その他」というのは給排気式 クリーンヒータやエアコン等, 室内の $\mathrm{NO}_{2}$ レベルにほ とんど寄与しないと考えられるものを一括している。次 いでガスストーブ $16 \%$ で，開放型 $\left(\mathrm{NO}_{2}\right.$ を初如，然焼 庰ガスを室内に排出する方式のもの，以下同じ）の中で 一番少なかったのは対流型石油ストーブ $6 \%$ であった。 また開放型をすべて合わせると $80 \%$ と高率であるが， 記戴不備で不採用としたものの約半效が“石油ストーブ” とのみ記しており，どの型であるのかを示さないもので あったことを考えると，開放型の使用比率は $90 \%$ を超 えるであろう。かねてわが国では開放型ストーブが暖房 器具の主力であると指摘されていたが，その実態が確認 された。

3-2-2 居間の広さ

すでに述べたように，居間の広さは「畳の数」で調べ た（有勃回答数：3886)。最も多かったのは 6 6.5 畳 で全体の $48 \%$ にもなり, 中でも 6 胃の和室がその大半 を占めていた。このことはわが国の家族構成や住宅事情 之密接に関連していると考えられるが，予想される極め て常識的な結果であろう。続いて 4 4.5 畳が $17 \% ， 8$ ～8. 5 畳が $13 \%$ の順であった。なお最小は 1 畳, 最大 は 31 畳であった。

\section{3-2-3 年間延べ暖房時間数}

年間延べ暖房時間数は一日の暖房時間 (冬期) に年間 の暖房期間（月效から日数に換算）を乗じて算出したも のであるが, 真冬に比べ秋口や春先では一日当たりの暖 房時間も短くなり，まったく暖房しない日もあるであろ うから，ここでの数値は多少過大気味になっているかも 知れない。さてその分布（有効回答数：3637）はほぼ 正規型であって，ピークは 500 699 時間にあり，平均 值は 980 時間であった。この値は一日 5 ～時間の 100 〜120日（3〜4 か月）という見当になり，京都市の気候 からは順当な値であるといえる(2)。なお最小は 50 時間,

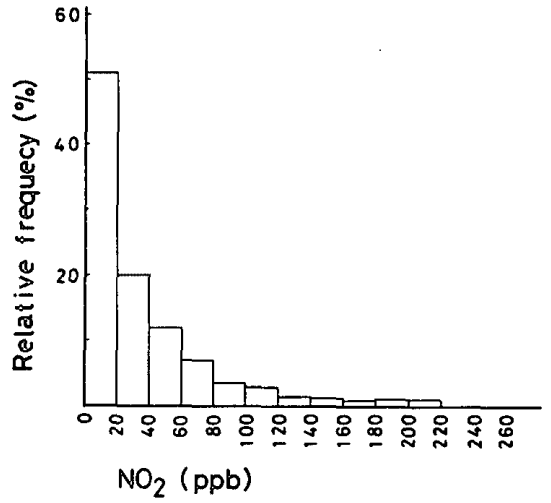

Fig. 6 Distribution of calculated indoor $\mathrm{NO}_{2}$ level

最大は 4400 時間であった。

3-3 $\mathrm{NO}_{2}$ 年平均室内灙度の推定值

質問紙配布調査で得られた諸デー夕をもとに，2-3 項 で述べた方法によって，対象世帯の居間個々について， $\mathrm{NO}_{2}$ 年平均室内瀥度を計算した。まずその统計量を示 すと次のとおりである。 $n: 3712$, 平均値 : $35.2(\mathrm{ppb})$, 標準偏差: 51.5 , 最大值: 717 , 最小値 : 0.0 , 中央値： 19.2。その分布の样子をヒストグラムで示すと図一6の とおりである。一番低いランクにピークを持ち，ランク 上昇とともに急激に減少する典型的なポアッソン型分布 を示す。この分布型は一般環境大気中の二酸化硫黄 $\left(\mathrm{SO}_{2}\right)$ や一酸化窒素 (NO) 濃度について認められる4)。 図一6 から分かるように，全体の $50 \%$ が $20 \mathrm{ppb}$ 圭満 となっている。そこで $20 \mathrm{ppb}$ 未満についてさらに調べ たところ，そのうちの $40 \%$ は $\mathrm{NO}_{2}$ ゼロ，つまり開放 型ストーブ以外の暖房器具を使用するものであった。し たがって開放型ストーブを使用し，かつ $\mathrm{NO}_{2}$ 蜄度が 20 $\mathrm{ppb}$ に満たないものは残りの $60 \%$ ，つまり全体では 30 \%ということになる。さて,この推定值の語価であるが， すでに述へできたうに計算に当たって仮定も多く，不 確定要素も沢山含んでいる。また初めての試みでもある ので,ここでは個々の値についての議論はひとまず置い て, 一つの代表値を求めて考察を進める。

代表値として最も一般的なものは平均值であるが，分 布の型が正規型から大きくずれているこの場合は余り適 当とはいえない。分布を正規型に近づけるためにしばし ば変数変換が行われる。そこでポアッンン型に対してよ く利用される平方根変換を行ったところ，最低のランク に依然としてピークを持つものの，その他の点ではかな りの程度で正規型に近くなった。この変換後の分布につ いて平均値を求め, しかるのち再び平方すると一つの代 表值が得られる。

またデータを小から大の方へ並べて，両側 $25 \%$ を カットした後, 平均をとる方法もよく行われる。

注 2）平均気温が $10^{\circ} \mathrm{C}$ 以下の日は年間 130 日前後である。 
このようにして求めた值を，先に示した中央値ととも に以下に示す。

平方根変換後平均値の平方 $: 21.8(\mathrm{ppb})$

両側 $25 \%$ カット後平均値 : $21.2(\mathrm{ppb})$

中 央 值

$: 19.2(\mathrm{ppb})$

これらの数值の相互比較から, 今回求めた屋内発生の $\mathrm{NO}_{2}$ の平均室内濃度はおおむね $20 \mathrm{ppb}$ とすることがで きるものと考える。

3-4 $\mathrm{NO}_{2}$ の “バックグラウンド” 值

さてそれでは大気中 $\mathrm{NO}_{2}$ のバックグラウンドはどの 程度になるのであろうか。ここでいう“バックグラウン ド”の意味は，今考察している部屋で暖房等の撚焼器具 を使用しない場合の $\mathrm{NO}_{2}$ の室内濃度という意味である。

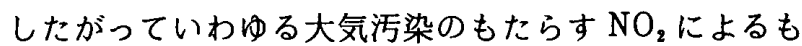
のを意味する。都市の屋外大気中 $\mathrm{NO}_{2}$ 濃度は随所に設 けられた観測局において，常時監視が行われている。そ こで, 各対象世帯ごとのバックグラウンドとして，過去 の観測データ4)をもとに，住宅の所在地ごと（市内を 29 の地区に分割）に年平均値を算出した。そしてさらに, そこから一つの代表值を得るために，こうして求めた地 区ごとの值に, 当該地区に属する対象世帯数を乗じて加 重平均を求めた。すなわち,

$$
\underline{C_{0}}=\Sigma \mathrm{Co}_{\theta} \cdot n_{\theta} / N \quad(N=2712, \theta=1 \sim 29)
$$

ここで Co は今回の対象世帯にかかわる平均の $\mathrm{NO}_{2}$ 年平均屋外濃度, $\mathrm{Co}_{\theta}, n_{\theta}$ はそれぞれ第 $\theta$ 地区の $\mathrm{NO}_{2}$ 年平均屋外濃度および有効回答世帯数である。この場合 $C o_{\theta}$ は最大值 : 28.0 , 最小值 : 0 であったが, ゼロの地 区（有効回答数は 38 で全体の $1.4 \%$ ）を除くと, 最小 值は 11.4 となって, レンジも比較的狭いので, 代表値 としては平均値で十分であると考えた。かくして求めた 値は次のようであった。

$$
\underline{C O}=19.7 \pm 5.0 \text { (S. D. ) (ppb) }
$$

真の $\mathrm{NO}_{2}$ 室内濃度は, 先に示した室内で発生した $\mathrm{NO}_{2}$ による濃度に, この屋外から侵入した $\mathrm{NO}_{2}$ がいわ ゆるバックグラウンドとして加算されることになる。侵 入した $\mathrm{NO}_{2}$ は（1）式にも示すように, 換気回数と反 応係数の相対值に依存して若干濃度低下を起こすことに なるが，詳細は不明であるので，ここでは濃度低下はな いものとする。そこで前項で求めた屋内起源の $\mathrm{NO}_{2}$ に よる濃度推算値と本項で得た屋外からの $\mathrm{NO}_{2}$ 濃度とを 比較照合すると，奇しくもほとんど等しい値となった。
すなわち京都市における一般住宅の居室内の $\mathrm{NO}_{2}$ は, 一つの代表值で考える限りにおいて，その $50 \%$ が屋外 から，残りの $50 \%$ が屋内発生という極めて簡明な結果 となった。

ところでこれは平均的な状況ということになるが，近 隣に大規模工場や交通量の多い道路があるような個々の 状況下では，屋外からの寄与が大きくなるであろうし， またその逆もあり得ることは当然である。

\section{4.おわりに}

本稿は，これまでに得られた $\mathrm{NO}_{2}$ に関する実験デー 夕を基礎に，広笧囲の人達の協力を得て暖房にまつわる 生活実態を調へ，現実の住宅における室内発生 $\mathrm{NO}_{2}$ の 平均的な濃度の推算を試みたものである。他方，バック グラウンドに相当する平均的な屋外濃度は実測デー夕か ら計算した。これら二種の値を比較照合したところ, 結 論は, $\mathrm{NO}_{2}$ の室内濃度に対する屋外起源 $\mathrm{NO}_{2}$ と屋内起 源 $\mathrm{NO}_{2}$ の比率は，50：50 ということになった。

これは一つの代表値による平均的な状況についての結 論である。個々の值について論じるにはなお検討すべき 課題が多い。ところで污染物質の濃度を平均值で評価す る方法は，人に対する影響を考えるとき，低濃度長時間 暴露と高濃度短時間暴露（ただし急性の影響が出ない範 用）は，その積が同じである限り，等価であるとする理 論に依拠している。二酸化窒素についてもそれでよいの かビうかは今後の研究を待つ外ない。データの充実と理 論の成熟を待って,さらに改善を図って行きたい。

\section{謝 辞}

質問紙調查に当たって，御協力いただきました方々に 厚く御礼申し上げます。また京都市衛生研究所福井 一研究主幹および同所疫学情報部門の皆様はじめ職場の 同僚の皆様には大変お世話になりました。記して謝意を 表します。

\section{引用文献}

1）山中伸一：屋内環境中の窒素酸化物に関する研究 然烧 器具別発生量および減哀過程に関する一考察, 日本建築 学会計画系論文報告集，第 357 号，23-31（1985）

2) Yamanaka S. : Decay Rates of Nitrogen Oxides in A Typical Japanese Living Room: Environ. Sci. Technol., 18, 566-570 (1984)

3）柳沢幸雄・西村 肇：生活環境漕度測定用 $\mathrm{NO}_{2}$ パーソナ ルサンプラー, 大気污染学会誌, 15, 316-323 (1980)

4) 昭和 55 年度大気污染常時監視測定結果, 京都市公害セン 夕- (1982) 


\section{SYNOPSIS}

UDC : $661.984: 628.85: 697.2$

\section{NITROGEN OXIDES IN $\mathbb{N}$ NDOOR IENVIRONRIENT (2)}

Estimation of annual mean nitrogen dioxide level in indoor living space with questionnaire method and calculation

by SHIN-ICHI YAMANAKA, Kyoto City Institute of Public Health, YURITAKA YAMAMOTO, Kyoto Municipal Junior College of Nursing, Members of A.I.J.

\section{Introduction}

The peak level of $\mathrm{NO}_{2}$ in a room can be derived from the steady state equation and expressed as ${ }^{2)}$ :

$$
C_{0}=E /((a+k) V)+a C_{0} /(a+k)
$$

where $C_{D}$ is the peak level of $\mathrm{NO}_{2}(\mathrm{ppm}), E$ is the $\mathrm{NO}_{2}$ emission rate for the source $\left(\mathrm{cm}^{3} / \mathrm{h}\right), a$ is air exchange rate $(1 / \mathrm{h}), h$ is sink rate of $\mathrm{NO}_{2}(1 / \mathrm{h}), \mathrm{V}$ is the air volume of the room $\left(\mathrm{m}^{3}\right)$, and $C_{0}$ is the outdoor level of $\mathrm{NO}_{2}$ (ppm).

In this paper, the decay parameter, $(a+k)$, was determined as to type of room in preliminary experiment; $V$ and other conditions of the room and the space heating of actual dwellings in Kyoto city were investigated with questionnaire method. $E$ was reported previously ${ }^{1)}$. Then the method of estimation of annual mean indoor $\mathrm{NO}_{2}$ level from the peak level was presented and the result was discussed.

\section{Preliminary Experiment}

With cooperation of 30 families, $\mathrm{NO}_{2}$ integrated concentration (ppb-day) in each living room was determined with the filter-badge method ${ }^{3)}$, and at the same time structure of house, type of room (Japanese style or western style, the area, etc.), condition of space heating (type of heater, net time of its operation) were investigated. $\mathrm{NO}_{2}$ collected by the filter-badge is proportional to the area under the curve shown in Fig. 1 (a). On the other hand, $(E / V) h$ corresponds to the area of the rectangle shown in Fig. 1(b). Then the ratio between $(E / V)(h / 24)$ and the measured integrated concentration (ppb-day) was analyzed for each house in detail ( $h:$ the net hours of heater operation during this experiment). In this case, the $\mathrm{NO}_{2}$ background level, which was obtained from air monitoring data, was subtracted from the latter, the measured value. The filter-badge was calibrated with automatic air monitor based on Saltzman's method and absorbance was converted into (ppb·day) (Fig. 2).

Hence the integrated value of indoor $\mathrm{NO}_{2}$ level can be calculated from :

$$
C(h)=(E / V)(h / 24)(1 / F)
$$

where $F$ is the decay parameter or may be named "correction factor" derived from the "ratio" described above. From the viewpoint of $F$ value, rooms were classified into four groups. They are as follows:

1. Japanese (kitchen-dining or adjacent to kitchen) $: 3.5$

2. Japanese (apart from kitchen) : 7.0

3. Western (kitchen-dining or adjacent to kitchen) $: 2.0$

4. Western (apart from kitchen) : 5.0

The correlation between $(E / V)(h / 24)(1 / F)$ and the measured values (ppb-day) in the preliminary experiment is shown in Fig. 4.

\section{Investigation with Questionnaire Mrethoo}

To each of 5000 families in Kyoto city ( $1 \%$ of all) sampled, questionnaire, which included the structure of house and other items described earlier in this paper, was sent out in June, 1985.

According to the answers collected, radiant kerosene heater was most widely used (36\%), fan heater and other heaters which don't emit $\mathrm{NO}_{x}$ indoors were the next (20\% each). All types of unvented heater reached a total of $80 \%$ (Fig. 5). Japanese style living room with six pieces of tatami, and 5-8 hours a day as heating time 
in winter, 3-4 months a year as heating season has been proved to be the most likely case.

Then annual means of $\mathrm{NO}_{2}$ level in indoor living spaces were derived from these informations combined with the decay parameters, " $F$ " as follows :

$$
C_{m}=(E / V)(h / 24)(1 / F)(1 / 365)
$$

where $h$ is the net hours of heating in a year (Fig. 3).

Their distribution is shown as a histogram in Fig. 6. It gives a typical Poisson's distribution. The statistics are as follows :

$$
n=2712 \text {, mean }=35.2, \text { S. D. }=51.5, \max =717, \min =0.0, \text { median }=19.2
$$

In discussing the result, one representative value is considered to be preferable to individual values because this calculation was carried out tentatively under several uncertainties. Such a value is 19.2 ppb (median) for example; mean is undesirable since the distribution is far from normal distribution. Incidentally it was comparable to the mean of $\mathrm{NO}_{2}$ outdoor level calculated from monitoring data ${ }^{4}$.

We can briefly conclude that in Kyoto city $50 \%$ of indoor $\mathrm{NO}_{2}$ level can be attributed to indoor-originated $\mathrm{NO}_{2}$ and another $50 \%$ to the outdoor-originated. 